\title{
An Approach for Life Cycle Assessment of Electricity Generation at Gas-HFO Internal Combustion Engines in a Central Station
}

\author{
Juan-Pedro Hernández Touset ${ }^{1}$, Jandecy Cabral Leite², Iván-Leandro Rodríguez Rico, \\ Alcimar de Jesus França ${ }^{3}$, Elena-Rosa Dominguez¹, Oiama de Assis Guedes ${ }^{3}$, \\ Italo-Jorge Tavares Jimenez ${ }^{2}$, Arnaldo Herrera Artiles ${ }^{1}$, Maylier Pérez Gil ${ }^{1}$ \\ ${ }^{1}$ Universidad Central "Marta Abreu” de Las Villas, Santa Clara, Cuba \\ ${ }^{2}$ ITEGAM-Instituto de Tecnologia e Educação Galileo da Amazônia, Manaus, Brasil \\ ${ }^{3}$ Companhia Energética Manauara S.A., Manaus, Brasil \\ Email: juanpedro@uclv.edu.cu, jandecycabral@hotmail.com, alcimarfranca@utemanauara.com.br
}

Received 5 July 2014; revised 10 August 2014; accepted 15 September 2014

Copyright (C) 2014 by authors and OALib.

This work is licensed under the Creative Commons Attribution International License (CC BY). http://creativecommons.org/licenses/by/4.0/

(c) (i) Open Access

\section{Abstract}

This paper applies the Life Cycle Assessment (LCA) as an assessment tool to quantify the environmental impacts associated with electricity generation by internal combustion engines. Steps, resources and/or supplies that have the greatest impacts during the life cycle of electricity generation are identified to contribute with measures of cleaner production in companies with similar power generation. The goal of this study is to evaluate the environmental impacts associated with the production of $1552 \mathrm{kWh}$ of electricity by gas-HFO internal combustion engines, considering a scenario that responds to use of lubricating oil, oily water treatment, collection and transportation of sludge. The study of additives and contaminants from lubricating oil is included, taking into account that it is a complex task for life cycle inventory considering limitations to get data. Arising from the use of the program SimaPro we get that the greatest impact are the lubricating oil use and transport on respiration of inorganic products and the use of fossil fuels. Most environmental impacts are concentrated in the use of lubricating oil and transportation.

\section{Keywords}

Additives, Internal Combustion Engines, Life Cycle Assessment, Lubricating Oil

Subject Areas: Chemical Engineering \& Technology, Environmental Sciences 


\section{Introduction}

The gas power plants are designed for optimal operation in a wide variety of decentralized energy production, among these, stationary plants. The motors are designed for continuous operation mode, natural gas or dual fuel gas and High Fuel Oil.

The company sets its own environmental policy and operates in accordance with the principles of sustainable development, however, and industrial emissions and waste from maintenance of the engines do not express the absolute truth of the environmental impacts [1].

The Life Cycle Assessment (LCA) applied at a power plant may have several benefits; its use for assessing the environmental impact of electricity generation may help to compare types of lubricants and fuels in engines and to assess lube and wastes impact.

In conventional thermal energy conversion in power plants, impacts connected to constructing the power plant or manufacturing the equipment are not important for the overall environmental impact of the electricity produced. A large portion of the environmental impact is connected to the production of electricity [2].

Primary life cycle inventory of the different types of lubricating oil additives, obtained from lab chemical and physical analysis is a good tool for assessing the environmental impact of lubricants and wastes. The novelty of this study lies on the information provided by the lubricating oil composition, sludge and waste water for further application of LCA methodology with extended boundaries.

In researching the environmental impact of lubricants, Wissol Autoexpress [3] considered the end of the lubricants life cycle, as the key stage for identifying the problems that may occur during the handling and disposal of used oil-based lubricants. For the LCA of the studied product, the information of the energy used and emissions generated by the different agents is required, which implies in most cases working with data from different and not homogenized sources [4].

In this context, LCA methodology was applied to examine the role of lubricating oil on electricity generation and the effect of considering its consumption in process equipments. The present study aimed to contribute to a better understanding of the influence of material and processes involved at a power plant in the results of LCA.

Based on potential impacts on human health and the environment, re-refining and distillation are significantly better practices than burning used oil as fuel [5]. From the environmental standpoint [6], the collection and storage of used lubricating oil (with subsequent regeneration of the lubricating oil by catalytic hydrogenation) reduces the environmental deterioration as it reduces the effects of incineration (air emissions) of used lubricating oil and uncontrolled discharge (water, soil contamination and groundwater).

The functional processes are also a problem for the LCA because not all functional flows are usually part of the same product system. Thus, a multifunctional process is part of the studied production system and of other systems too. The challenge is to allocate the environmental impacts of this process to the different multifunctional product systems, i.e. to the different functional flows [7]. The most frequently used methods for solving this problem are subdivision, system expansion, physical and economic partition and replacement. Several authors have argued that replacement is conceptually equivalent to system expansion [8] [9].

The energy in the form of electricity is an important input into many industrial processes, and as there are several alternatives for energy production, many LCAs on electricity production have been carried out at numerous institutes and companies throughout the world [10]. This research focuses on lubricating oil subsystem and the generated electricity as the output product to technosphere. Used lubricating oil subsystem is not considered.

On the other hand, taking into consideration the LCA benefits related with the incorporation of different types of lubricating oil additives, it was necessary to review some important theoretical views on this topic. The additives are substances formulated to enhance antifriction properties, chemical and physical properties of base oils (mineral, synthetic, vegetable or animal) which result in improved performance of the lubricant and so the equipment life extension. The amount of additives may be up to $30 \%$ [11].

The additives have different functions and usually belong to the categories of friction modifiers (Graphite, Molybdenum Disulfide, Boron Nitride, Tungsten Disulfide, Polytetrafluoroethylene), antiwear (Zinc Dithiophosphate (ZDP), Zinc Dialkyl Dithiophosphate, Tricresyl), extreme pressure additives (chlorinated paraffins, sulfur fats, Esters, Zinc Dialkyl Dithiophosphate, Molybdenum Disulfide); rust and corrosion inhibitors (alkaline compounds, organic acids, esters, amino-acid derivatives ), antioxidants (Zinc Dithiophosphate, alkyl sulfides, aromatic sulfides, aromatic amines, hindered phenols), detergents (phenolates, sulfonates and phosphonates of 
alkali and alkaline-earth elements such as calcium, magnesium, sodium or barium); dispersants (Polyisobutylene Succinimides) pour point depressants (Polyalkyl Methacrylate Copolymers ) viscosity index improvers (Polymeric Acrylate) and antifoaming agents (Dimethylsiloxanes).

Raimondi [12] integrates and expands the previous LCAs of oil-based lubricants and also examines the additives contribution of a fully formulated lubricant to the environmental impact. In this case, the additive contribution to the life cycle impacts of commercial lubricating oil was found to be nearly $35 \%$ to global warming. The main sources of data for the LCA were the Boustead Model [13], Ecoinvent [14], European Reference Life Cycle Database-ELCD [15] and the report IFEU/GEIR [16]. The last one reports that the composition of lubricating oil can be $80 \%$ of oil-based lubricants (mineral/synthetic), $2 \%$ of detergents, $6 \%$ dispersants, $9 \%$ viscosity modifiers (olefin copolymers), 1\% antioxidant (Zinc Dialkyl Dithiophosphates/Phenols) and 2\% antiwear (Zinc Dialkyl Dithiophosphates). LCA models proposed phases include extraction, transportation and production to the output of the refinery/factory. The allocation criterion for the outputs is mass. The main conclusion is that in modern lubricants, additives contribution in terms of environmental impact can be significantly high and therefore should not be excluded. Ekman and Börjesson [17] admit that in applications where the amount of additives can be up to $30 \%$, the environmental consequences are significant and ultimately recommend to include additives in future LCAs.

Since new components of lubricating oils blended with conventional additives are emerging there are not enough data for the implementation of LCA. On the other hand, manufacturers of additives and lubricants are extremely conservative and rarely are willing to provide data and information. This paper is structured as follows. Firstly a critical analysis of the literature on various aspects related to the application of LCA is given. Then, the elements to be taken into account to define the goal and scope of the study and life cycle inventory for the environmental impact assessment are suggested, as well as a discussion on the availability and understanding of the data and the influence of additives on LCA for future research of alternative scenarios in the life cycle of used lubricating oils and oily wastes.

The goal of this study was to assess the environmental impacts of electricity generation by natural gas-High Fuel Oil internal combustion engines, considering a scenario that responds to use of lubricating oil, oily water treatment, collection and transportation of sludge. Also the environmental profile of electricity generation system is examined using Eco-indicator 99 method to obtain the total contribution of the process for each one of the impacts categories in correspondence with the study conditions.

\section{Materials and Methods}

The reason for analyzing the LCA of electricity generation is to provide the power plant with a systematic framework to identify, quantify, interpret and evaluate the environmental impacts of electricity generation from internal combustion engines.

\subsection{Goals and Scope Definition}

The goal of this study is to assess the environmental impacts associated with the production of $1552 \mathrm{kWh}$ of electricity by gas-HFO internal combustion engines, considering a scenario that responds to the use of lubricating oils, oily water treatment, collection and transportation of sludge.

As an analytical tool, LCA facilitates the information for decision-making and identification of opportunities for improvement. The analysis, evaluation and proposals for the application of LCA to lubricating oils are in correspondence with the standards of ISO 14040, 14041, ISO 14042, and ISO 14043.

\subsubsection{Function and Description of the Power Plant and the Lubricating Oil System}

The power plant has an installed capacity (total power of generation) of 85,380 kW, composed of 5 groups of Wärtsilä generators with an engine gas/HFO cycle of medium rotation, each of 17,076 kW continuous power at ISO conditions, at $514 \mathrm{rpm}$. The gas is carried directly by pipes to the engine hall from the supplier. The plant operates with a power demand of $63 \mathrm{MW}$, delivering 525,600 MWh/y of electric power, and consumes 11310 MWh/year during $8700 \mathrm{~h} /$ year and a specific fuel consumption of $209 \mathrm{~g} / \mathrm{kWh}$. For engine lubrication the plant uses Marbrax CCD 430 mineral oil. Figure 1 shows the flowchart of the lubricating system.

The oil is pumped back to the carter through a plate cooler. The centrifugal separator unit keeps the fuel and lubricant quality by removing water and sludge. 200 liters per day of lubricating oil is restored in the crankcase 


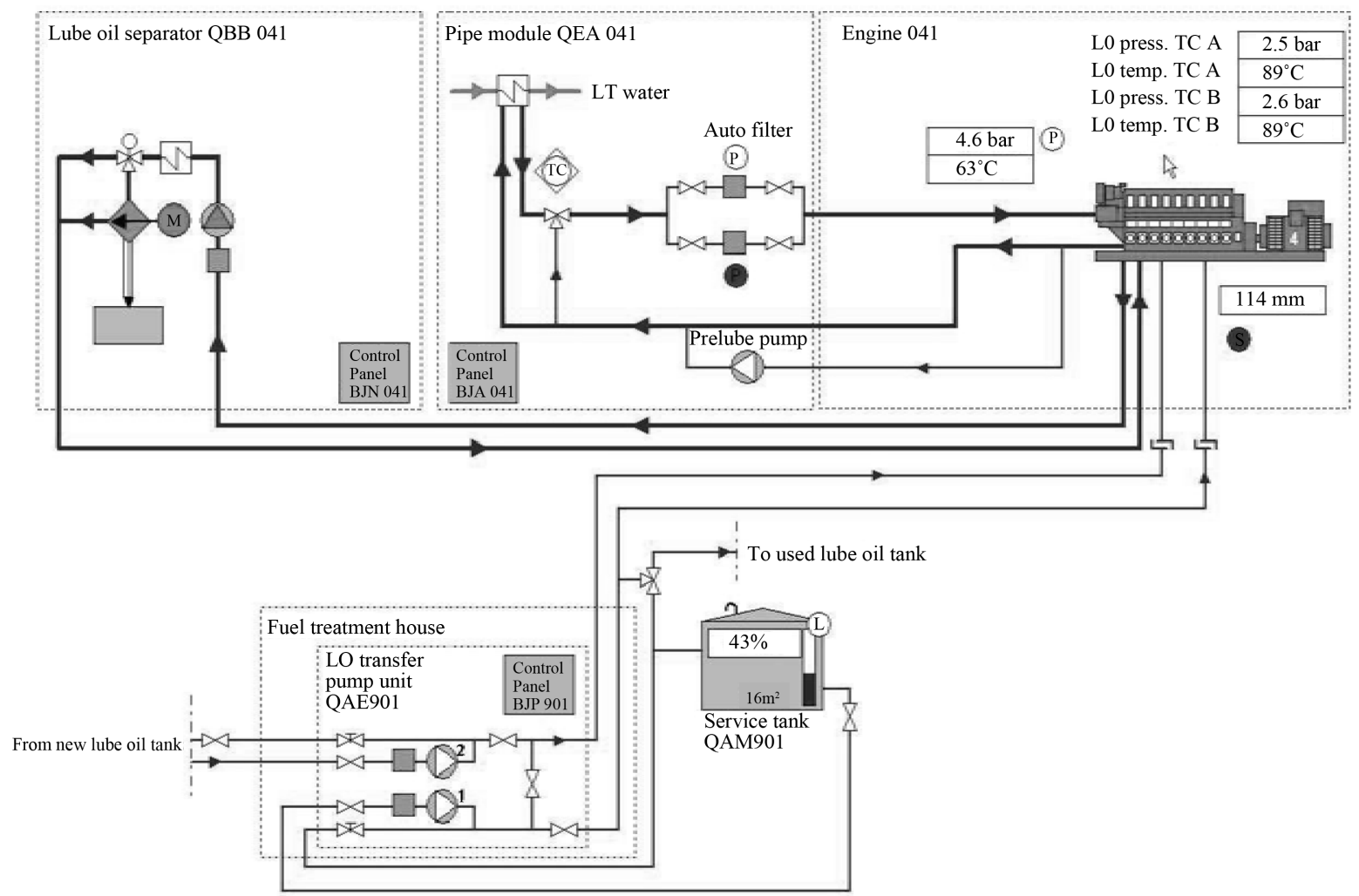

Figure 1. Lubricating oil system.

due to separation of sludge, burning in the engine jacket, saturation of the filter elements and other small losses. The process water is supplied from a well. The lubricating oil is supplied from a storage tank of $60 \mathrm{~m}^{3}$. In case

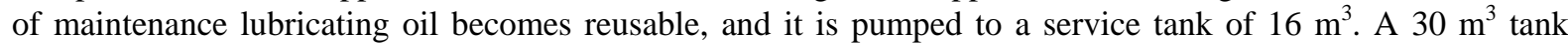
receives used motor lubricating oil. When the tank is full it is discharged into tank trucks of environmental companies. Figure 2 shows the oily water system. Oily water and sludge generated in the plant are stored in a box and separated into oily water and sludge. The water is sent to a processing unit by dissolved air flotation system. The treated water suitably mixed with other flows and effluents is discharged to the environment. Sludge and HFO (fuel) averaged $1000 \mathrm{~kg} / \mathrm{d}$ are collected in a tank of $55 \mathrm{~m}^{3}$ and transported to a collector enterprise.

\subsubsection{Setting System Boundaries}

The system boundaries for the case study are in correspondence with those shown in Figure 3 by dashed lines. Multiple scenarios for lubricating oil treatment can be defined, and therefore the boundaries for the application of LCA may be different depending on the quality of data available for each option. The system, in general, starts with the use of lubricating oil in the internal combustion engines. In the setting boundaries stage, electricity generation is defined as the main system and oil cleaning in the separation unit and the oily water treatment is considered a subsystem.

Therefore it is necessary to know the operations of the lubricating system and materials and energy flow between them. For doing this the process tree is designed and it is represented in Figure 3, which shows the life cycle model for electricity generation used in a power plant.

\subsubsection{Allocation Rule of Environmental Loads and Main Assumptions}

In the lubrication stage an environmental load distribution is applied as function of mass percent that represents each output stream of the stage regarding to the total. The environmental load allocation is performed in order to evaluate the actual impact of the stream involved in the analysis; in the study the allocation criterion is mass. The main product is the electric energy. 


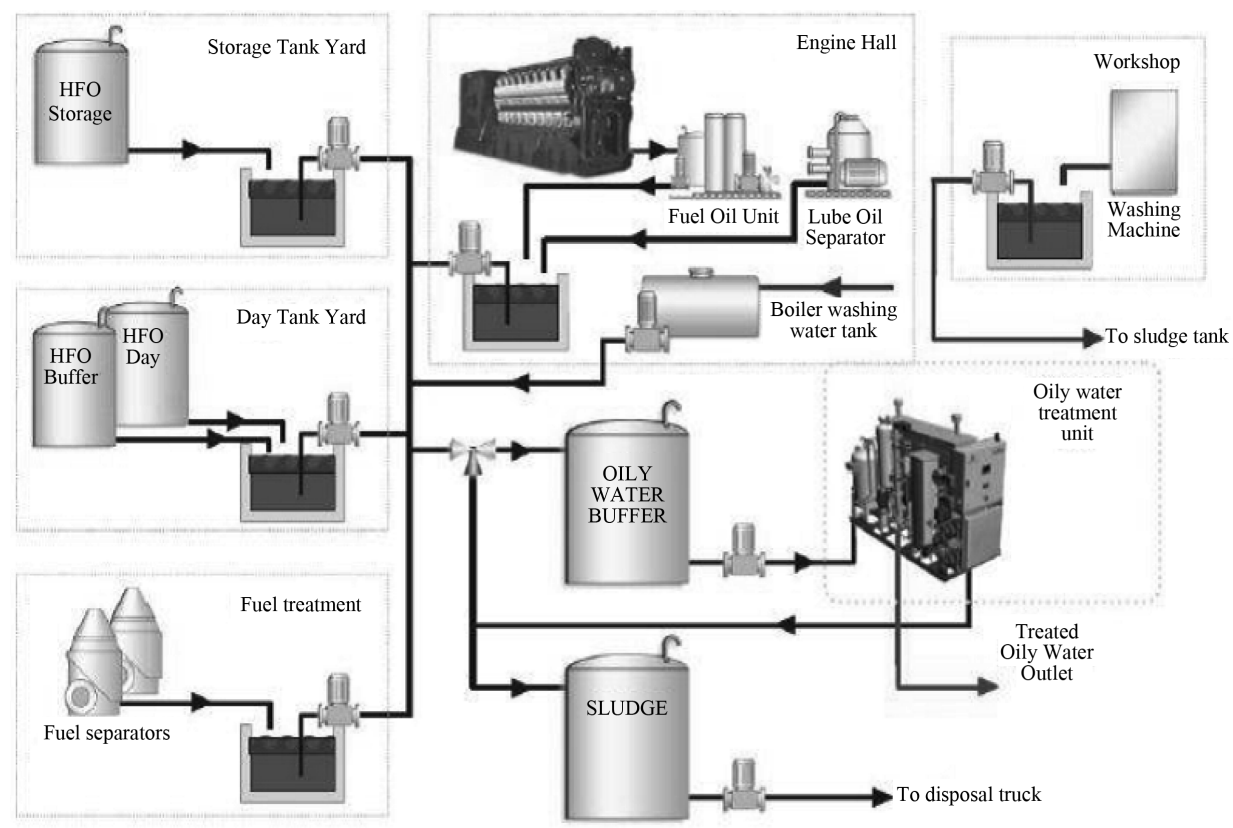

Figure 2. Diagram of oily water collection and treatment unit.

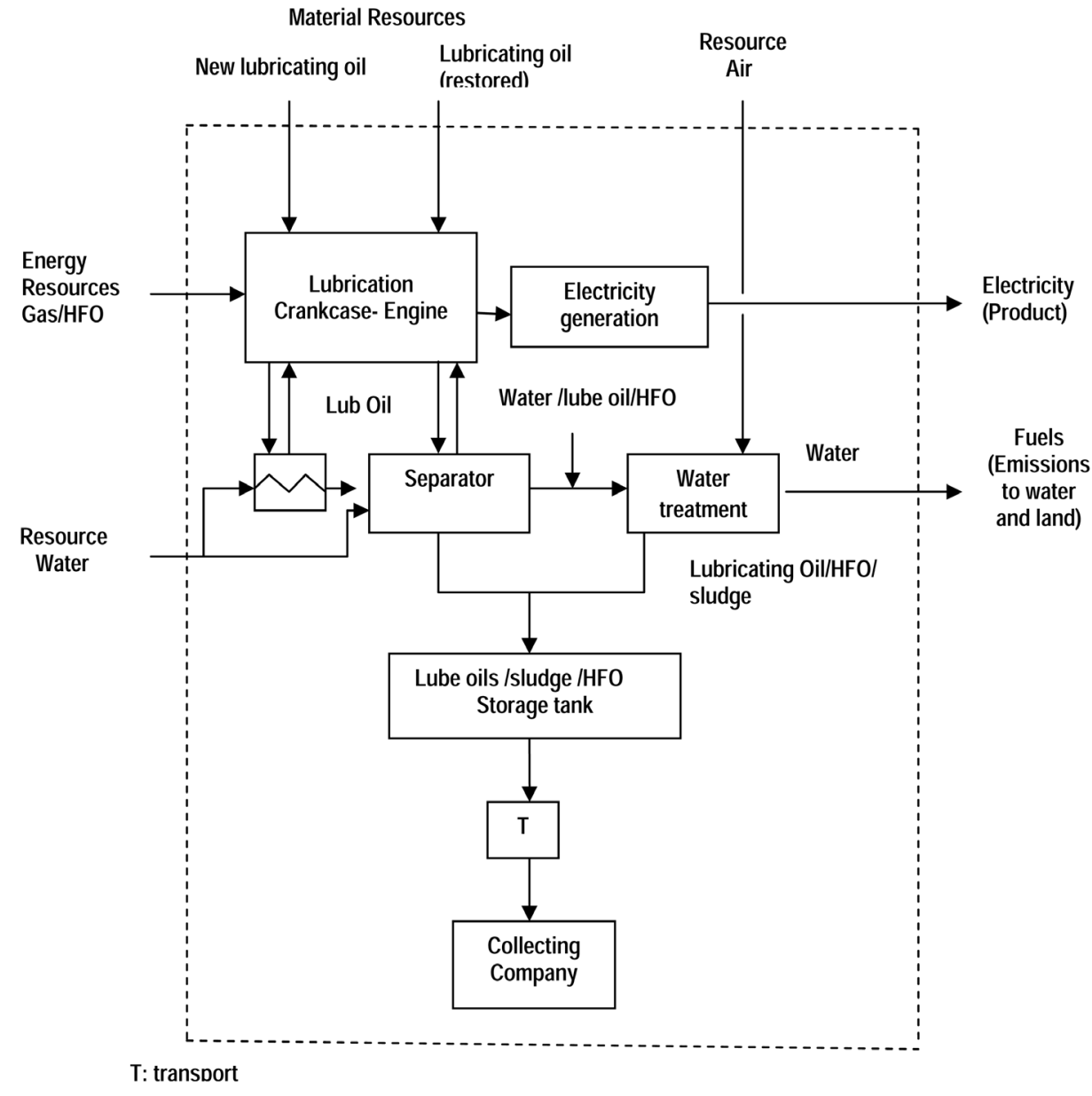

Figure 3. Process tree. 
The avoided product is considered the mixture sludge/HFO by replacing the use of Diesel in combustion at industrial plants.

The adopted assumptions during the study are listed below:

-It has been established as a functional unit an amount of $1512 \mathrm{MWh} /$ day.

-Sludge/HFO is considered avoided products, since they avoid the use of equivalent amounts of Diesel for combustion in industrial plants.

-Exhaust gases are excluded.

-Production of lubricating oil, maintenance and solid waste are not considered, but these may be included in other studies.

-Systematic chemical analyses for evaluating the oil type and concentration of additives in the databases are carried out.

-Mass balance results for the lubricating and oily water treatment system are used.

-Impact assessment is carried out without including consumed electricity at lube oil separators, since electricity is produced by the power plant.

-Transportation of 20 tons of sludge/HFO in tanker trucks, traveling $40 \mathrm{Km}$ every 20 days.

\subsection{Life Cycle Inventory}

In the lubricating and oily water system, primary data were taken from operating reports, literature and specialists' criteria.

It has been considered that the data meet the quality indicators for a proper interpretation of LCA results and has been kept in mind: 1) validity of the data (temporary), which correspond to the same year in implementing the LCA; 2) geographical coverage, where the data correspond to an operating plant; 3) accuracy, since the work has been done with the extreme value when the data match a range of values and 4) representativeness, since process-specific database are used, database and referenced literature are also used, considered a mature and modern technology.

\subsection{Life Cycle Impact Assessment}

Methodology of Eco-indicator 99 for the assessment of environmental impacts is applied, using the SimaPro 6.0 software. 11 impact categories considered in the Eco-indicator 99 are assessed with weighting based on the hierarchical cultural perspective (Eco-indicator 99 (H) V2.1/Europe EI 99 H/H).

These categories are related with three damage categories (human health, ecosystem quality and resources) [18]-[22]. Materials, resources and products used in the assessment were taken from Ecoinvent database, developed by Ecoinvent Center, Swizerland.

\subsection{Study Interpretation}

The whole system analysis, weak points and better alternatives were determined from the environmental point of view. As results of the evaluation, the final contribution of the inventory data, the network process, environmental profiles in impact and damage categories in tabular and graphical form were obtained, allowing determining the stages and most striking system.

\section{Results and Discussion}

\subsection{Analysis of Life Cycle Inventory}

In correspondence with SimaPro software, the categories for the inventory data are:

-Inputs from the Ecosphere (natural resources).

-Inputs from Technosphere (products, resources, human activity).

-Outputs to Technosphere (products, by-products).

-Ecosphera Emissions (emissions).

Table 1 shows the results of physical and chemical analyses to the treated water discharged into the water/soil [23], where the most significant value is the concentration of oils and fats. 
Table 1. Results of physical and chemical analyses to the treated water discharged into the water/soil (MICRO-LAB, 2012).

\begin{tabular}{cccc}
\hline Parameters & Unit & Sample & M.P.V. \\
\hline COD & $\mathrm{mg} \mathrm{O}_{2} / \mathrm{L}$ & 139.0 & N.A. \\
Total phenols & $\mathrm{mg} \mathrm{C}_{6} \mathrm{H}_{5} \mathrm{OH} / \mathrm{L}$ & 0.00 & up to 0.5 \\
Phosphorus & $\mathrm{mg} \mathrm{P} / \mathrm{L}$ & 2.8 & N.A. \\
Nitrate & $\mathrm{mg} \mathrm{N} / \mathrm{L}$ & 1.4 & N.A. \\
Nitrite & $\mathrm{mg} \mathrm{N} / \mathrm{L}$ & 0.00 & N.A. \\
Oil and Fats & $\mathrm{mg} / \mathrm{L}$ & 17.00 & up to 20.0 \\
Dissolved oxygen & $\mathrm{mg} \mathrm{O} / \mathrm{L}$ & 3.1 & N.A. \\
Settleable solids & $\mathrm{mg} / \mathrm{L}$ & $<1.00$ & Up to 1.0 \\
Dissolved solids & $\mathrm{mg} / \mathrm{L}$ & 350.00 & N.A. \\
Suspended solids & $\mathrm{mg} / \mathrm{L}$ & 26.00 & N.A. \\
Sulfites & $\mathrm{mg} \mathrm{S} / \mathrm{L}$ & 0.47 & up to 1.0 \\
Sulfates & $\mathrm{mg} \mathrm{SO} / \mathrm{L}$ & 15.00 & N.A. \\
Turbidity & $\mathrm{NTU}$ & 32.00 & 31.00 \\
Temperature & ${ }^{\circ} \mathrm{C}$ & up to 100.0
\end{tabular}

M.P.V.: Maximum permissible values by article 16 of resolution CONAMA 430 of May 13, 2011. N.A.: Not applicable.

\section{Lubricating Oil Additives}

Due to the absence of specialized literature on the topic and the low availability of primary data, a simplified methodology is adopted [12] to carry out the LCA considering the impact of the additives in the lubricant and wastes. It involves:

1) Identification of the category of the additive used in lubricating oil: lubricating oil Marbrax CCD 430 has antioxidant, anti-corrosion, anti-wear, anti-foam, detergent, dispersant, alkaline reserve agent and pour point depressant [24] (LUBRAX, 2011) and additives to 14\% [25];

2) Selection of a representative additive for each category, which can be taken from physical and chemical analysis results;

3) Identification of the correspondence between the selected additive and the industrial product available in the database Ecoinvent Data V 1.01 [14].

Figure 4 shows the chemical analysis results to the lubricating oil Marbrax CCD 430 using infrared spectrometry with ASTM E2412 FFT version JOAP/Tribolab [26] and Figure 5 shows the physical-chemical analysis results of the lubricating oil using ASTM D6525, atomic emission spectrometry improved by Tribolab, which determines the wear particle concentration ( $\mathrm{Fe}, \mathrm{Cr}, \mathrm{Sn}, \mathrm{Al}, \mathrm{Ni}, \mathrm{Cu}, \mathrm{Pb}, \mathrm{Mo}$ ), additives concetration (Ca, Mg, B, $\mathrm{Zn}, \mathrm{P}, \mathrm{Ba}$ ) and contaminants concentration ( $\mathrm{Si}, \mathrm{Na}, \mathrm{Va}$ ). The last one with low variation but of great importance in diagnoses since it can provide information regarding the composition of the waste oil and sludge.

Corresponding to Figures 4, Figure 5 and Table 1 [23], the information provided by FDSPQ [25] and a sludge analysis report (HFO) from Intertek [27], Table 3 summarizes the main data and assumptions for additives, contaminants and wastes. In this analysis a representative additive for each category of additive and contaminants is adopted, which subsequently allows identifying the chemical in the software database.

Table 2 shows the concentrations and the amount of additives and contaminants and also the concentration and amount of oil and grease in wastewater that is discharged into the environment, according to the analysis.

Table 3 reports the results of inventory data of all stages according to the inventory categories. The inputs and outputs of process stages were inventoried in correspondence to the mass and energy balances, indexes reported in the literature and previous studies.

\subsection{Life Cycle Impact Assessment}

In this section results for life cycle inventory assessment previously showed are discussed. 
Infrared Spectrometry with FFT ASTM 2412 version JOAP/Tribolab (Abs/cm)

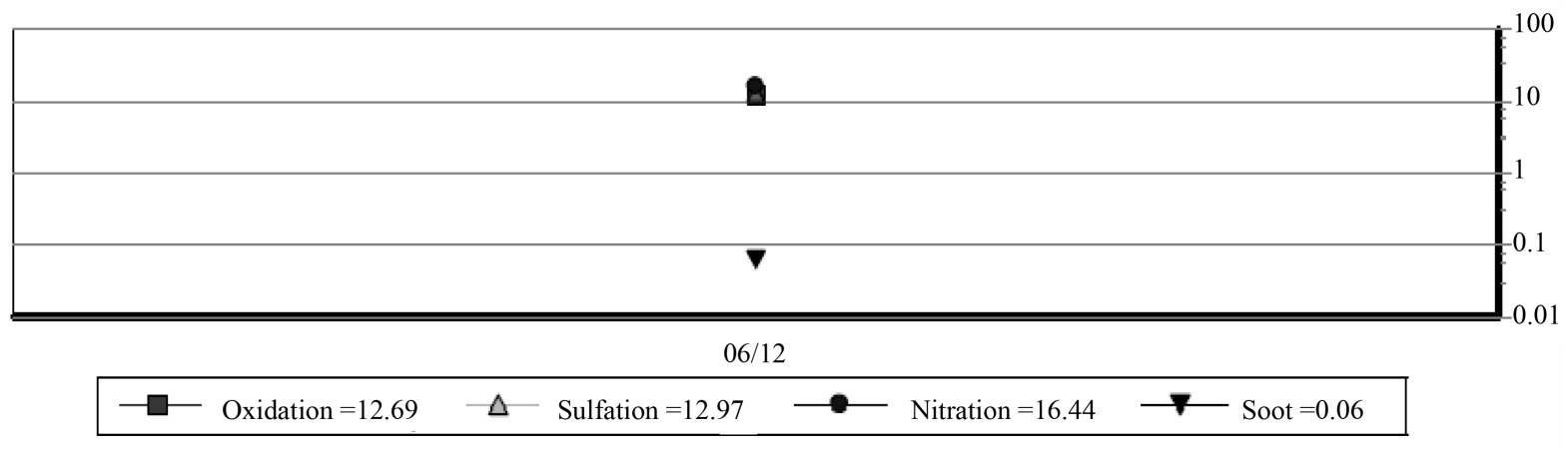

Figure 4. Infrared spectrometry to marbrax CCD 430 lubricating oil.

Atomic Emission Spectrometry ASTM D6525 improved by Tribolab $(\mathrm{ppm}=\mu \mathrm{g} / \mathrm{g}=\mathrm{mg} / \mathrm{Kg}$ )

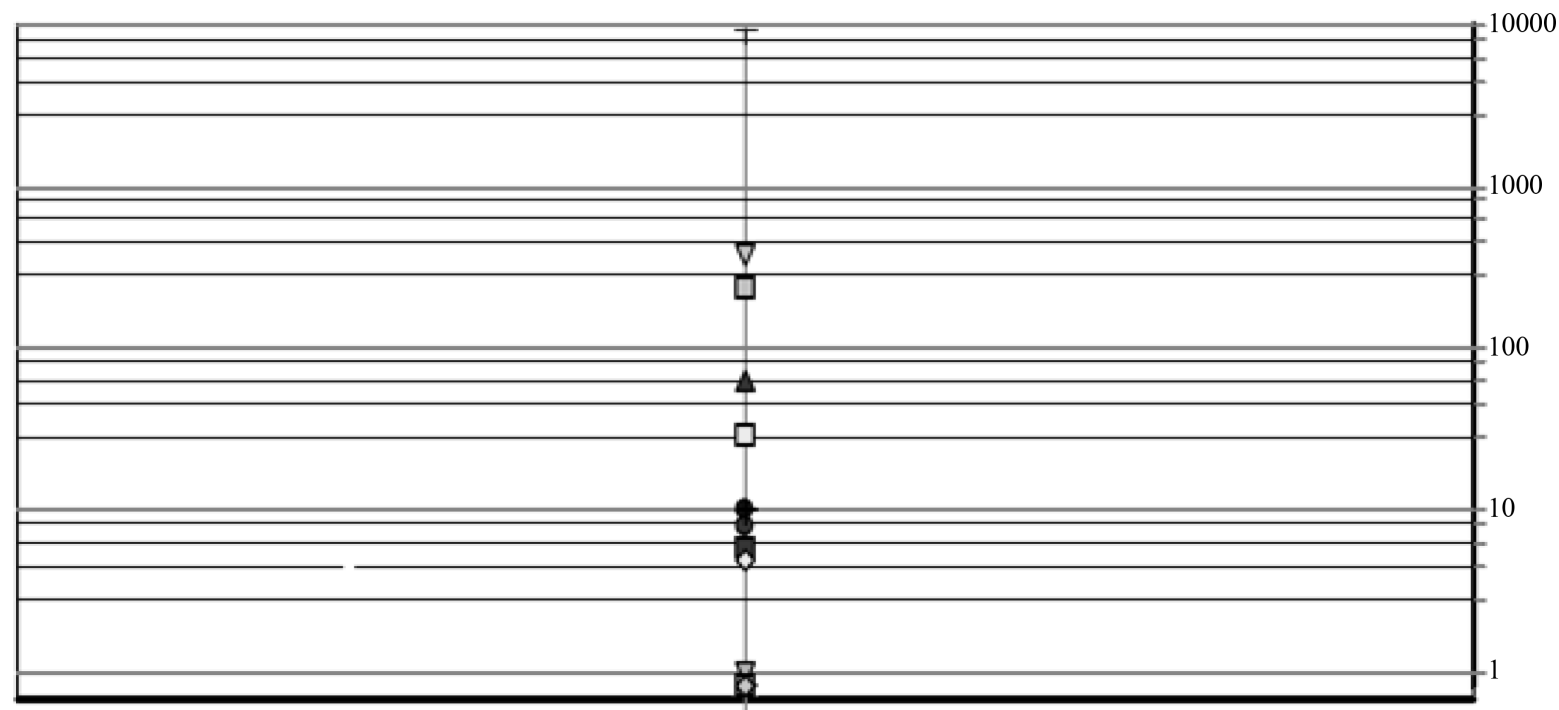

$06 / 12$

\begin{tabular}{|c|c|c|c|c|c|c|}
\hline$-\bullet \mathrm{Fe}=10$ & $-\nabla-\mathrm{Cr}=1$ & $-\mathbf{P b}=0$ & $-\square-\mathrm{Ou}=6$ & - Sn $=0$ & $\longrightarrow \mathrm{Ni}=8$ & $\lessdot \mathrm{Ag}=0$ \\
\hline$-\circ-\mathrm{Si}=8$ & $\square-\mathrm{B}=0$ & $\square \mathrm{Na}=30$ & $-\mathbf{t}-\mathrm{Mg}=64$ & $+\mathrm{Ca}=9433-\square-\mathrm{Ba}=0$ & $-\square-P=236$ & $\nabla-\mathrm{Zn}=387$ \\
\hline$-\square-\mathrm{Mo}=0$ & $-0-\mathrm{Ti}=0$ & $+\mathrm{V}=10$ & & & & \\
\hline
\end{tabular}

Figure 5. Atomic emission spectrometry to marbrax CCD 430 lubricating oil.

\subsubsection{Characterization}

In Figure 6 the characterization of the system express the percentages (\%) each material represents for impact categories (carcinogenesis, organic compounds respiration, inorganic compounds respiration, climate change, radiation, ozone layer, ecotoxicity, acidification/eutrophication, land use, minerals and use of fossil fuels) without considering electric consumption at lubricating oil separators. The contribution of lubricating oil, considered as an input in the system boundaries established to the LCA is high and the contribution of transport is lower. In the categories of radiation, ozone layer, ecotoxicity and respiration of organics, lubricating oil contributes in more than $90 \%$ to the environmental impact.

It is logical that the categories with the most impact are ozone layer, radiation, ecotoxicity, and respiration of organics and the use of fossil fuels.

\subsubsection{Weighting}

Materials weighting is analyzed in Figure 7 without considering electric consumption at lubricating oil separa- 
Table 2. Main suppositions and data for LCA at power plant.

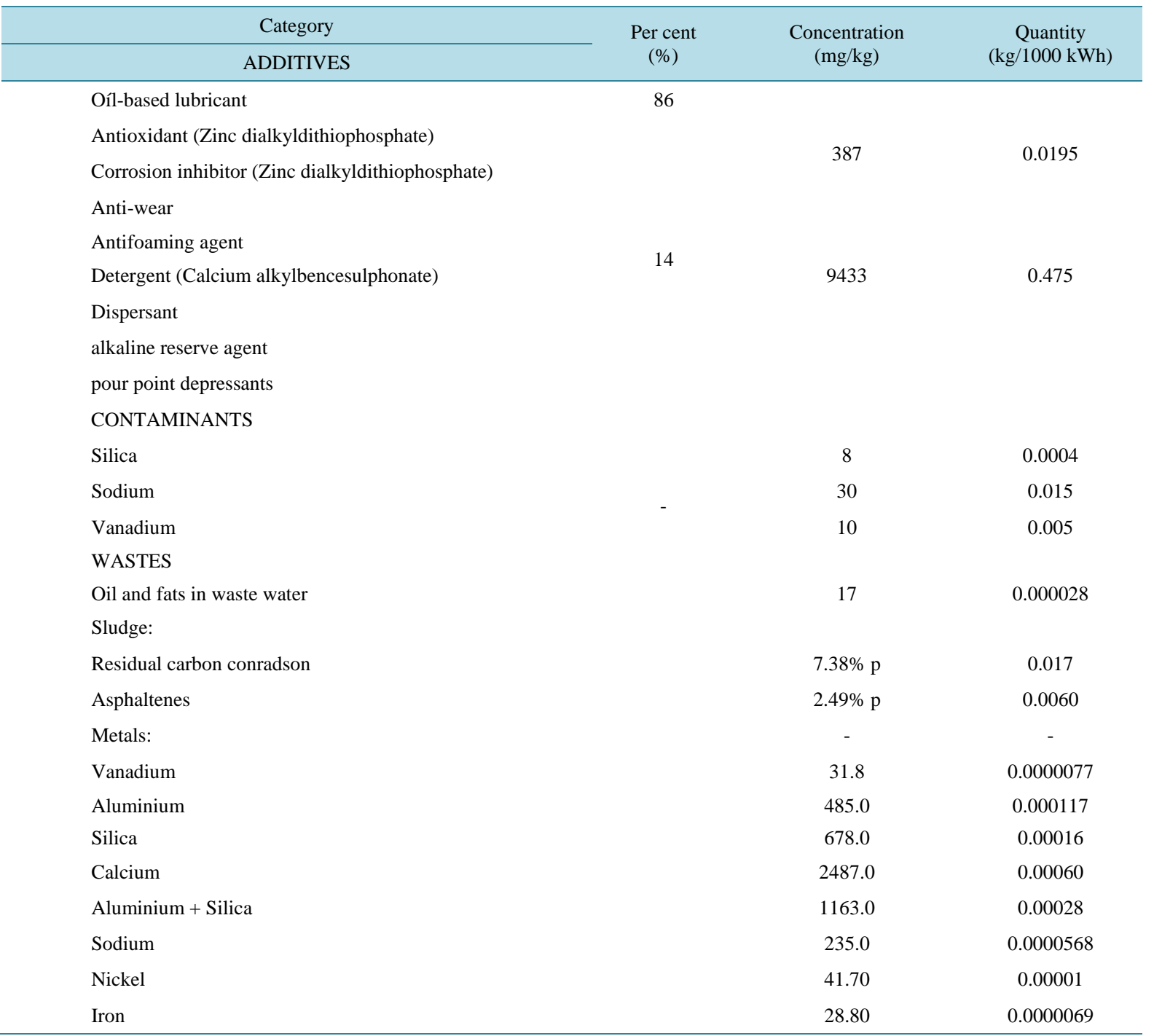

Table 3. Life cycle inventory.

\begin{tabular}{|c|c|c|c|c|c|}
\hline \multicolumn{2}{|c|}{ Known outputs to technosphere. Products and co-products } & Amount & Unit & Quantity & Comments \\
\hline \multicolumn{2}{|l|}{ Electric energy } & 1512 & $\mathrm{MWh} / \mathrm{d}$ & Energy & Company handbook \\
\hline \multicolumn{2}{|c|}{ Known outputs to technosphere. Avoided products } & Amount & Unit & Distribution & \\
\hline \multicolumn{2}{|c|}{ Diesel } & 0.73 & $\mathrm{t} / \mathrm{d}$ & Normal & Operating reports \\
\hline Known inputs from nature (resources) & Subcompartment & Amount & Unit & Distribution & Comments \\
\hline \multicolumn{2}{|l|}{ Process water } & 1.652 & $\mathrm{t} / \mathrm{d}$ & Normal & Operating reports \\
\hline \multicolumn{2}{|l|}{ Air } & 1.22 & $\mathrm{~m}^{3} / \mathrm{d}$ & Normal & Operating reports \\
\hline \multicolumn{2}{|l|}{ Lubricant oil } & 0.720 & $\mathrm{t} / \mathrm{d}$ & Normal & Operating reports \\
\hline \multicolumn{2}{|l|}{ Gas to engines } & 300 & $t / d$ & Normal & Operating reports \\
\hline \multicolumn{2}{|l|}{ HFO to engines } & 15.8 & $t / d$ & & Operating reports \\
\hline Emissions to water & Subcompartment & Amount & Unit & Distribution & \\
\hline Hydrocarbons, non specified & Water & 0.000028 & $t / d$ & Normal & MICRO-LAB, 2012 \\
\hline \multicolumn{2}{|l|}{ Water } & 1.552 & $t / d$ & Normal & Mass balance \\
\hline
\end{tabular}




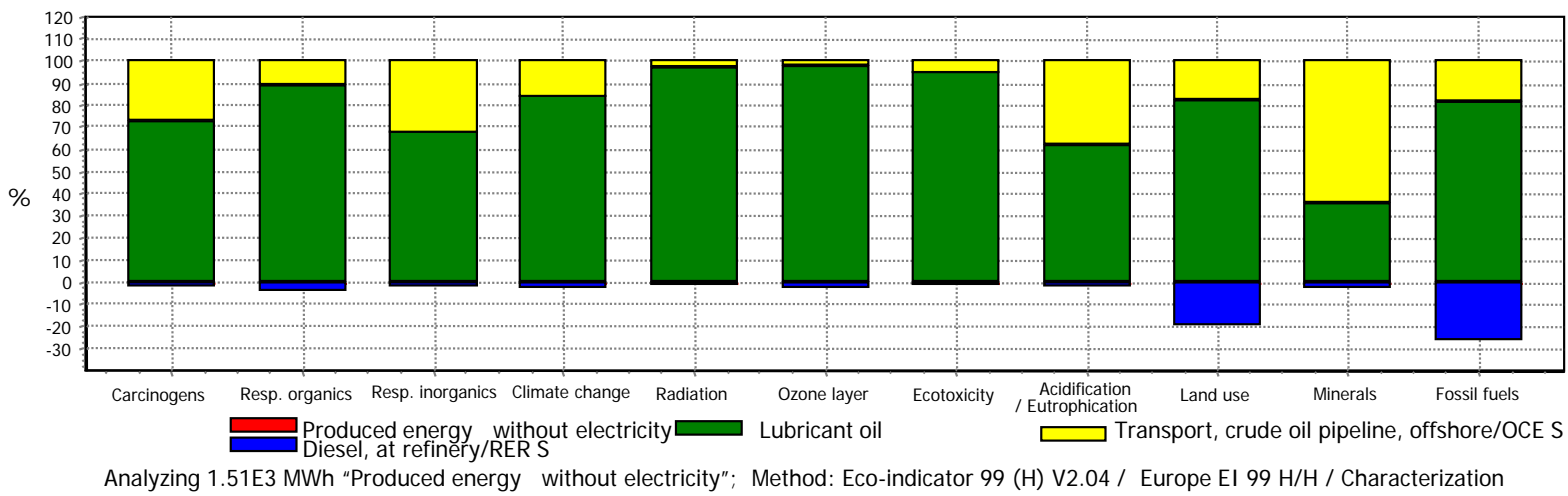

Figure 6. Environmental impacts without considering electric consumption at lubricating oil separators.

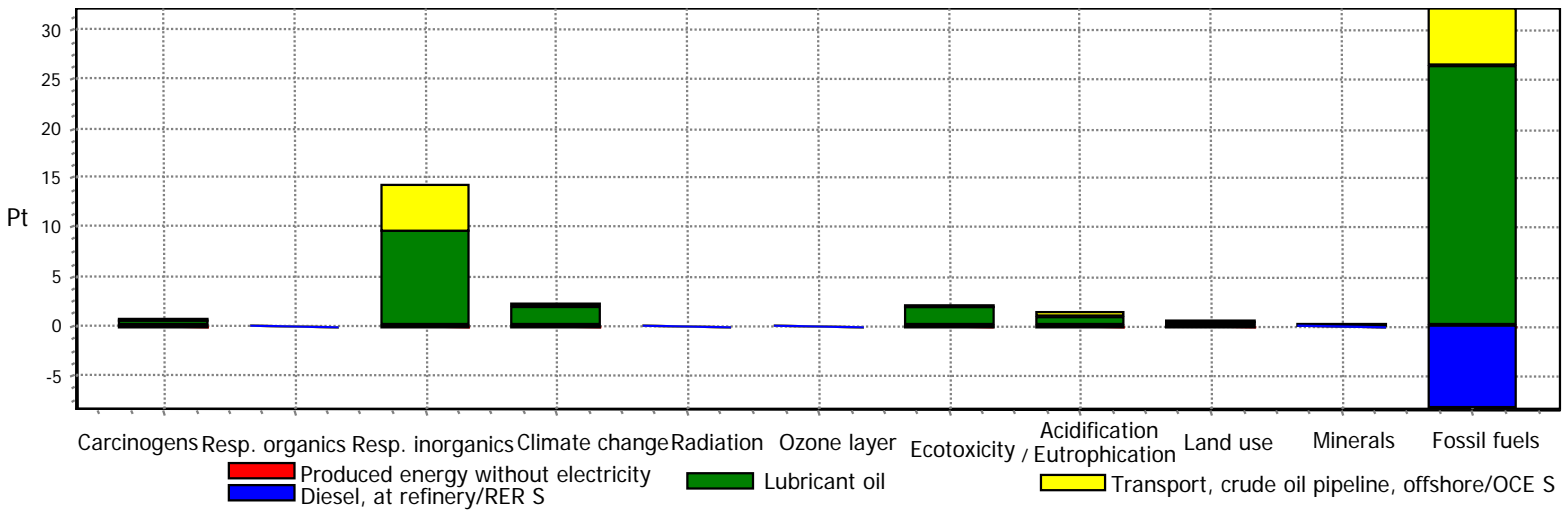

Analyzing 1.51E3 MWh 'Produced energy without electricity'; Method: Eco-indicator 99 (H) V2.04 / Europe El 99 H/H / Weighting

Figure 7. Materials weighting on environmental impact categories.

tors. It has been analyzed how each impact category is affected for all the materials involved in the electric generation. It is noted again that the biggest impact are the use of lubricating oil and transport on respiration of inorganics as well as the use of fossil fuels.

\subsubsection{Single Score}

Figure 8 shows the effect in Pt (impact points) that has the lubricating oil of internal combustion engines, transportation and damage avoided by reusing HFO and sludge wastes, on the 11 environmental impact categories. A major influence is on the exhaustion of fossil fuels and respiration of inorganics in lubricating oil and transport.

\section{Conclusions}

This study is a contribution in terms of the particularities to be taken into account in the steps of goal and scope of the study and in the step of life cycle inventory, which is brought to the power plant fundamental characteristics of LCA as an analytical tool for decision-making and the identification of opportunities for improvement.

The contribution to the environmental impact by materials indicates that the effect of the use of lubricating oil is minimal.

A reference LCA Model and data for life cycle inventory is apported which can be examened in further studies.

The impact evaluation of electricity generation system by means of Eco-indicator 99 and SimaPro software reported beneficial impacts on the carcinogenesis, radiation, ecotoxicity and land use categories, because of the reduction of emissions to the air, water and land by concept of avoided products.

Most environmental impacts are concentrated in the use of lubricating oil and sludge transportation on respiration of inorganics and the use of fossil fuels. 


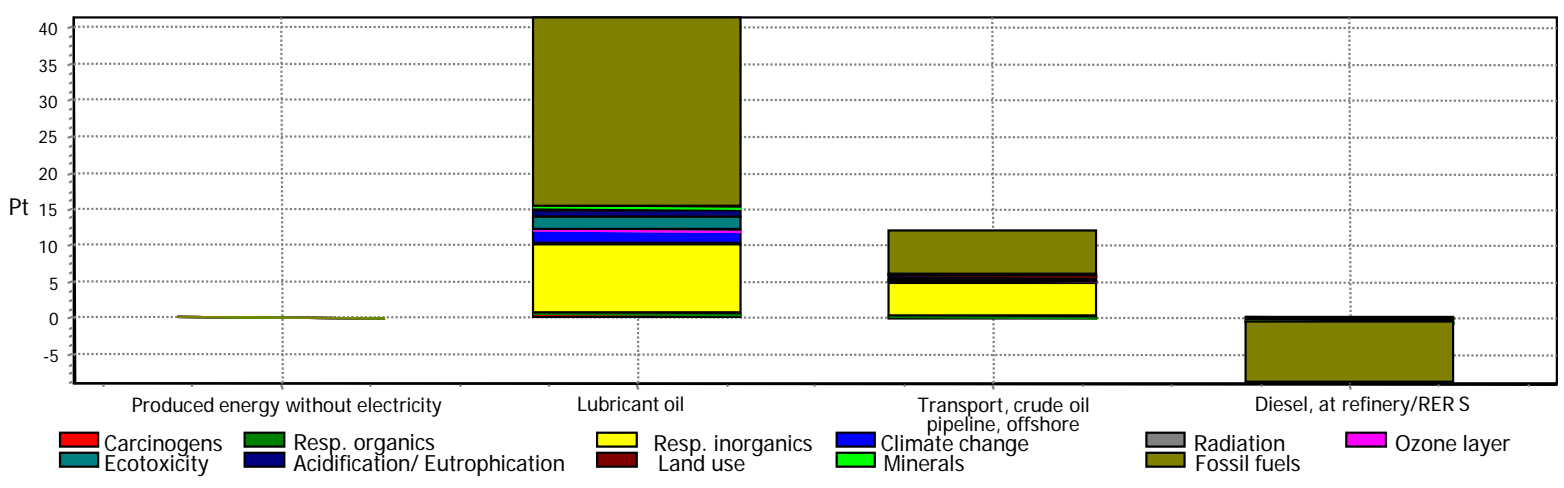

Analyzing 1.51E3 MWh "Produced energy without electricity"; Method: Eco-indicator 99 (H) V2.04 / Europe El 99 H/H / single score

Figure 8. Processes effects on impact categories without considering electric consumption at lubricating oil separators.

The application of LCA to lubricating oils is not only from the operational point of view. The inclusion of additives in the LCA is a complex task, considering the limitations in information, however additives inventory contributes significantly in identifying chemicals in the waste oil and sludge, which have a marked effect on the environment.

It is recommended for further studies to include Life Cycle Inventory (LCI) data of lubricants in LCAs of products and services.

LCA methodology is a scientifically based tool to assess the environmental impact generated by the use of lubricants in internal combustion engines at power plants.

An EIA (Environmental Impact Analysis) has been made to identify and assess possible environmental impacts associated to electricity generation.

The power plant practices good housekeeping and operating practices including inventory control to reduce the amount of waste.

The power plant does not have significant impacts on the quality and quantity of ground water and the treated effluent is disposed within the permissible limits of regulations into the wastewater drainage system.

This work may be taken as a reference for future developments of LCAs on lubricants, considering the inclusion of additives.

The study allows comparing the environmental impacts of processes and materials involved in similar power plants.

\section{Acknowledgements}

Institute of Technology and Education Galileo of Amazonas (ITEGAM) and Manauara Thermoelectric Plant (UTE Manauara), for providing information and financial support for this research.

\section{References}

[1] Skrotski, B. and Vopat, W. (1960) Power Station Engineering and Economy. McGraw-Hill Companies, New York, $751 \mathrm{p}$.

[2] Bai, L. (2012) Life Cycle Assessment of Electricity Generation from Low Temperature Waste Heat. The Influence of Working Fluid. Department of Energy and Process Engineering, Norwegian University of Science and Technology, Trondheim.

[3] Wissol Autoexpress (2012) About Lubricants. Online. Accessed: 2012-1-18.

http://www.wissolautoexpress.ge/index.php?eng\&cat=91\&type=1.

[4] UPC ( 2012) ACV. Estado del conocimiento. 29-41, Online. Accessed 2012-2-3. http://upcommons.upc.edu

[5] Boughton, B. (2004) Environmental Assessment of Used Oil Management Methods. Environmental Science \& Technology, 38, 353-358. http://dx.doi.org/10.1021/es034236p

[6] EPEM (2012) Innovative Collection System and Life Cycle Assessment for Waste Lube Oils. Task 6: Life Cycle Assessment-Conclusions. Innovative Collection System and Life Cycle Assessment for Waste Lube Oils LIFE02 ENV/ GR/000360. Online. Accessed 2012-1-10. http://www.epem.gr/icol/pdfs/task_6_a.pdf 
[7] Wardenaar, T., et al. (2012) Differences between LCA for analysis and LCA for policy: A Case Study on the Consequences of Allocation Choices in Bio-Energy Policies. The International Journal of Life Cycle Assessment, 17, 10591067. http://www.springeropen.com/journals http://dx.doi.org/10.1007/s11367-012-0431-x

[8] Ekvall, T. and Tillman, A. (1997) Open-Loop Recycling: Criteria for Allocation Procedures. The International Journal of Life Cycle Assessment, 2, 155-162. http://dx.doi.org/10.1007/BF02978810

[9] Finnveden, G. and Lindfors, L. (1998) Data Quality of Life Cycle Inventory Data—Rules of Thumb. The International Journal of Life Cycle Assessment, 3, 65-66. http://dx.doi.org/10.1007/BF02978486

[10] WEC (2004) Comparison of Energy Systems Using Life Cycle Assessment. World Energy Council. Accessed: 20134-20.

http://www.worldnuclear.org/uploadedFiles/org/WNA/Publications/Working_Group_Reports/comparison_of_lifecycle . $\mathrm{pdf}$

[11] Kopelioivich, D. (2012) Additives in Lubricating Oils. (online). http://www.substech.com

[12] Raimondi, A., Girotti, G., Blengini, G.A. and Fino, D. (2012) LCA of Petroleum-Based Lubricants: State of Art and Inclusion of Additives. The International Journal of Life Cycle Assessment, 17, 987-996. http://www.springerlink.com http://dx.doi.org/10.1007/s11367-012-0437-4

[13] Boustead Model 5.0 (2005) Operating Manual. Boustead Consulting Ltd., Horsham.

[14] Ecoinvent (2006) Life Cycle Inventories of Chemicals-Ecoinvent Report No. 8. Swiss Centre for Life Cycle Inventories, Zürich and Dübendorf.

[15] European Commission (2010) ELCD Core Database Version II.

[16] Fehrenbach, H. (2005) Ecological and Energetic Assessment of Rerefining Used Oils to Base Oils: Substitution of Primarily Produced Base Oils Including Semi-Synthetic and Synthetic Compounds. Institut für Energie- und Umweltforschung GmbH (IFEU), a Study Commissioned by GEIR-Groupement Européen de l’Industrie de la Régénération. [online] http://ec.europa.eu/environment/index_fr.htm

[17] Ekman, A. and Börjesson, P. (2011) Life Cycle Assessment of Mineral Oil-Based and Vegetable Oil-Based Hydraulic Fluids Including Comparison of Biocatalytic and Conventional Production Methods. The International Journal of Life Cycle Assessment, 16, 297-305. http://dx.doi.org/10.1007/s11367-011-0263-0

[18] Contreras, A.M., Rosa, E., Pérez, M., Van Langenhove, H. and Dewulf, J. (2009) Comparative Life Cycle Assessment of Four Alternatives for Using By-Products of Cane Sugar Production. Journal of Cleaner Production, 17, 772-779. http://dx.doi.org/10.1016/j.jclepro.2008.12.001

[19] Goedkoop, M. and Spriensma, R. (2001) The Eco-Indicator’99. A Damage Oriented Method for Life Cycle Impact Assessment, Methodology Report. 3rd Edition, PRé Consultants, Amersfoort. http://www.pre.nl

[20] Pérez, M. (2009) Evaluación ambiental del proceso de cogeneración con bagazo en la Industria Azucarera Cubana mediante el Análisis del Ciclo de Vida. Tesis presentada en opción al grado científico de Máster, Universidad Central de Las Villas, Santa Clara.

[21] Pérez, M., Contreras, A.M., et al. (2013) Life Cycle Assessment of the Cogeneration Processes in the Cuban Sugar Industry. Journal of Cleaner Production, 41, 222-231. http://dx.doi.org/10.1016/j.jclepro.2012.08.006

[22] PRé Consultants (2004) SimaPro End User License Agreement (EULA) and Service Level Agreement (SLA). http://www.pre.nl

[23] MICROLAB (2012) Relatório analítico RA 173/12. http://www.laboratoriomicrolab.com.br

[24] LUBRAX-PETROBRAS (2011) Ficha técnica MARBRAX CCD. http://www.br.com.br/wps/wcm/connect/da160d00465086cf8cb8ddffd66dff26/fispq-lub-embarcacoes-marbrax-ccd.pdf ?MOD=AJPERES

[25] FDSPQ (2011) Ficha de Datos de Seguridad de Producto Químico MARBRAX CCD. http://www.br.com.br/wps/wcm/connect/da160d00465086cf8cb8ddffd66dff26/fispq-lub-embarcacoes-marbrax-ccd.pdf ?MOD=AJPERES

[26] TRIBOLAB (2012) Relatório de exame. Lub: MARBRAX CCD 430/440. http://www.tribolab.com.br

[27] Intertek (2011) Relatório de análise óleo combustível 1A. GERA-Geradora de Energia, Candeias. 